\title{
The Application of Experiential Teaching Mode in College English Teaching
}

\author{
Baohua Zhang \\ Zhejiang Yuexiu University, Shaoxing, China \\ Email: judy0428@163.com
}

How to cite this paper: Zhang, B.H. (2021) The Application of Experiential Teaching Mode in College English Teaching. Open Access Library Journal, 8: e7534. https://doi.org/10.4236/oalib.1107534

Received: May 17, 2021

Accepted: July 6, 2021

Published: July 9, 2021

Copyright (C) 2021 by author(s) and Open Access Library Inc.

This work is licensed under the Creative Commons Attribution International License (CC BY 4.0).

http://creativecommons.org/licenses/by/4.0/

\begin{abstract}
With the rapid development of the world's economy and politics, English has become more and more important. In China, college English is a compulsory course for higher education, however, the traditional college English teaching can not satisfy the needs of modern college students. Experiential Teaching Mode has made up for the shortcomings of traditional classroom teaching. It enables students not only to participate in experience environment to gain corresponding experience but also to improve their communicative ability and intercultural communicative competence. This article firstly summarizes the background, discusses the necessity and feasibility of applying Experiential Teaching Mode in college English teaching. Secondly, it reviews the development and study of experiential teaching both at home and abroad. Thirdly, it talks about the significance, strategies of applying Experiential Teaching Mode in college English teaching, meanwhile it also summarizes the existing problems of current experiential teaching practice in college English and gives some possible solutions. Hoping that with the cooperation of teachers and students, the application of Experiential Teaching Mode in college English teaching can achieve good teaching effects and help students improve their English levels.
\end{abstract}

\section{Subject Areas}

Language Education

\section{Keywords}

Experiential Teaching Mode, College English Teaching, Experience, Experiential Teaching

\section{Introduction}

With the development of globalization, cooperation in business and trade be- 
tween countries has deepened. Meanwhile, with the help of the "One Belt, One Road" strategy, the economic and cultural exchanges between China and the countries along the road have also become more frequent. English, as the main official language of the United Nations, has become one of the most important communication tools in international business trade and intercultural exchanges. To satisfy the great needs of communication, English communicative competence becomes especially crucial. Experiential Teaching Mode, which is to create experience environment based on the classroom teaching objectives and content, has been widely acknowledged by scholars and teachers. Teachers design and create a relevant experience environment according to teaching content and students' conditions. Students enter and participate in the environment to master the knowledge and obtain the corresponding experience so as to improve their English level.

English is a compulsory course for college students in China. In traditional college English teaching, most classes are "teacher-centered", teachers focus on delivering knowledge, emphasizing the ability of reading and writing, neglecting the abilities of speaking, listening and communicating. With the implementation of the college English Curriculum Requirement, college English classes have been transformed to "students-centered", however, problems that can not be neglected still exist. Firstly, students are lack of interaction in class. Most Middle school students focus their English study on reading, writing and grammar so as to get high scores in the College Entrance Examination. In Middle school English classes, students tend to depend on teachers and are used to "teacher-centered" classes. They spend quite a lot of time memorizing words and grammar, doing a lot of reading comprehension but seldom speaking or communicating with others in English [1]. All these result in the problem of high score but low proficiency. Secondly, students are deficient in autonomous learning ability. They have long been used to the teacher-centered learning style and thus unconsciously put themselves in the passive role of organizing, reflecting and evaluating their English learning. They are incapable of planning their English learning by themselves. Thirdly, students can not achieve satisfying learning outcomes. The scale of the class, the teaching modes, the whole learning process are so different from those in their senior schools that some students feel lost or even complain their English proficiency declined after a year of college English learning.

On the other hand, experiential teaching, which emphasizes on the emotional experience of both teacher and students, is an interactive learning and teaching mode. During the teaching process, information, emotions and feelings between teachers and students is exchanged. Teachers are expected to create a free and pleasant learning atmosphere for students by offering help, showing respect, listening to them and accepting different opinions. Under such a favorable atmosphere, students are motivated to learn freely and actively and can deal with the problems and difficulties in the learning process.

For the above reasons, Experiential Teaching Mode was introduced to college 
English teaching, aiming at developing students' ability to use English in all-round way so that they can exchange information effectively through different channels in their future work and interactions.

\section{Literature Review}

Experiential Teaching Mode originates from psychology, aesthetics, philosophy, etc. In psychology, experience means a special mental activity, i.e. the profound understanding of things and the feelings about things based on the actual sensing. From the perspective of aesthetics, experience is described as "the deeper feelings of the readers generated when appreciating beauty, which are lively, attractive and indulging and accompanied by intense and dramatic inner activities as well as active and pleasant emotions" [2]. From the point of philosophy, experience can be divided into two categories: ontological experience and cognitive experience. Ontological experience refers to an approach to existing while cognitive experience is considered as an approach to perceiving things.

\subsection{Studies Abroad}

Experiential teaching was first put forward by the American pragmatic educator John Dewey. His idea was "Education is life. Education is the transformation of one's experience" [3]. He set up the first students-centered school and advocated experiential learning. Students were encouraged to gain experience through activities and the interaction between subjectivity and objectivity. "Learning by doing" was the essence of his education thoughts. In the $17^{\text {th }}$ century, John Locke claimed "Education is an experience". In the learning process, students created new knowledge through interaction with the previous experience. In the 1940s, Kurt Hahn noticed the problem in school education and realized that it could not satisfy the students' development need. He motivated students to improve their viability through experiencing challenge and adventure. Based on these, David A.Kolb published a book entitled Experiential Learning-Experience as the Source of Learning and Development. He illustrated his ideas about experiential learning in details in the book. According to Kolb, knowledge results from the combination of grasping and transforming experience. The experiential learning process is the integration of experience, perception, cognition, sharing, behavior and reflection [4].

\subsection{Studies at Home}

Studies about experiential teaching and learning in China have a longer history. The great Ancient Chinese thinker and educator Confucius ever said, "To listen extensively, choose to follow what is good, to observe extensively to gain knowledge, are next to knowledge" [5]. Confucius taught his disciples to gain knowledge both from textbooks and from personal experience. He made his disciples understand and experience the value and real meaning of life. Chinese famous 
educator Tao Xingzhi also proposed his theories of Life Education. His opinion was "Teaching should be integrated with learning and doing" "Knowledge is the rule of action. Action is the work of knowledge" [6]. He considered both action and doing as experience. Modern Chinese scholars also study experiential teaching a lot. Wang Na introduces Experiential Teaching Mode, analyzes the problems in applying it in teaching and gives some possible solutions [7]. Wang Jing applies the Experiential Teaching Mode in college English teaching and realizes that it is very helpful in cultivating students' autonomous learning ability [8]. You Shuxia and Wang Shasha applied Experiential Teaching Mode to the Tourism English teaching and found that this teaching mode is good for students' emotional attitude and value development [9]. The theoretical teaching research values of the Experiential Teaching Mode is widely recognized by scholars and teachers and the application of it to the classroom teaching has also achieved notable effects.

\section{The Application Significance of Experiential Teaching Mode in College English Teaching}

Experiential Teaching Mode values the students' initial and specific experience and the accumulation of it. As a teaching method, it emphasizes the transformation of the content learned autonomously to students' own knowledge and the mastery of it. Unlike the traditional "teacher-centered" teaching mode, Experiential Teaching Mode is "students-centered". It focuses on experience, the conclusion and reflection of the experience to gain further experience and knowledge accumulation. Students first participate in the environment created by teachers and will gradually integrate into it. With the help of teachers, they will discover, establish and construct their own subjective knowledge framework. Moreover, in the process of experiential learning, students can obtain more direct experience to connect and further integrate into the fragmented knowledge content. Finally, students will obtain more in-depth knowledge accumulation.

Experiential Teaching Mode can cultivate students' emotion and purify their soul. Like a filter, it can purify and sublimate people's soul by eliminating the negative emotions. The purified emotional experience has better cognitive functions such as regulation, adaptation, and directing property. Experiential Teaching Mode can also cultivate students' creativity and adaptability. It influences the students after extracting and purifying the experience from society and daily life. Situations and settings such as model education, picture description, role-playing, poetry reading, painting, music appreciation and sightseeing all can be used for experiential teaching. In other words, the specified setting in experiential teaching can arouse some certain hidden cues, which can bring new cognitive structure. For example, teachers design corresponding role-playing activities by combining the teaching content of visiting a tourist attraction, students can get some corresponding experience of introducing a place to others. When meeting foreigners visiting a tourist spot, students can volunteer to be the guide with the 
help of the relevant experience.

Experiential teaching is to create a relaxed, interactive teaching environment so that students can participate in it freely and actively. In college English teaching, teachers create the communication environment with matching language and culture, students can choose different scenarios according to their own level and experience. Thus students can form knowledge on language learning and application, job workflow, social development and other aspects. From this point of view, Experiential Teaching Mode is more suitable for language teaching. The "students-centered" teaching mode runs through the whole college English teaching process, providing students with a lot of opportunities for practical application of theoretical knowledge. It can improve students' oral expression ability, establish a multi-cultural view and better communicate with others. College students face fierce competition in the job market after graduation, such knowledge can bring more possibilities for their future career development.

\section{Application Strategies of Experiential Teaching Mode in College English Teaching}

\subsection{Incorporate Modern Technology to Create Experience Environment}

In applying Experiential Teaching Mode to college English teaching, teachers should make good use of information technology and the multimedia technology to create various of rich and realistic experience environment for students and teachers to better interact with each other and can further enhance the experiential teaching environment.

College English learning and teaching resources include a variety of sound, images, video and dynamic text which require a more vivid and experiential learning atmosphere [10]. In college English classes, teacher teach students language skills and theoretical knowledge, they should also focus on improving students' communication ability and intercultural communicative competence.

English dubbing, English debate, English speeches, English role-playing can be made into micro-videos to be shared with students before class. In class, teachers would encourage students to use the communication scenes in the video for reference while interacting with their classmates on the basis of their preliminary cognition of theoretical knowledge. After class, teachers can assign problem situations or specific situational tasks. Based on different experience environment created with the help of modern technology, students can gain abundant learning experience, express opinions in English in a more relaxing atmosphere and make themselves into talents with rich theoretical knowledge, good cultural literacy and strong professional skills.

The scientific integration of modern technology into college English teaching can not only provide students with more focused and unscrupulous conversations and ideas but also enables them to gradually transform from language learning and communication dimension to the height of cultural communication. 


\subsection{Make Full Use of the Foreign Teacher Resources and Extracurricular Activities to Create Immersive Experience Environment}

The ultimate goal of college English teaching is to enable students to effectively construct knowledge system, freely communicate with others and gradually develop intercultural communicative competence. In the process of applying Experiential Teaching Mode to college English teaching, teachers should make good use of the English corner and extracurricular activities to create an immersive experience environment for students.

Schools and teachers can hold different competitions or activities to provide more opportunities to create immersive experience environment. Students can put their theoretical knowledge into practice by debating, writing, presenting, acting or role-playing in the extracurricular activities. On the other hand, teachers can make good use of the foreign teacher resources by inviting them to classes or the English corner activity. Thus students can immerse in a real transnational and cross-cultural communication scene. Through communication in such environment students can test their English learning achievements and also experience the concrete feelings of interacting with people from different cultural backgrounds.

By creating immersive experience environment, teachers can help students enter into a specific context of communication. Students can also eliminate the troubles brought by cultural differences and better transfer their mother language.

\subsection{Focus on the Interaction and Communication between Teachers and Students}

In classroom teaching, communication and interaction between teachers and students is the most important factor. Good communication can help students achieve goals more quickly.

In the experiential teaching classroom, teachers create different experience environment, students should enter the situation and experience the role to gain corresponding situational experience so that they can improve their integration into the situation. During the process teachers and students need to communicate and interact with each other repeatedly. Teachers should guide students to fully participate in experiential teaching, thus they can timely know students' learning process and stimulate their autonomous learning and self-evaluation. Meanwhile, students should discuss with the teachers whenever they have difficulties, thus they can fully understand their own problems in participating in experiential teaching. Only in this way can students deepen the impression of the experience and English knowledge learned in the experiential learning so as to lay a solid foundation for the follow-up discussion and communication with students. Through communication and interaction students will absorb the experience actively, produce deeper understanding, improve their listening ability and communication skills. 


\subsection{Organize the Students' Good Participation in the Experience Environment}

The application of Experiential Teaching Mode is beneficial to mobilize students' enthusiasm and interest in learning. The "students-centered" teaching mode is carried out by interactive activities which require students to participate in a variety of experience environment so that they can get subjective experience feelings and experience results. In classroom teaching, teachers can enhance students' participation by guiding them to actively participate in experiential teaching, summarizing their own experience process and carrying out reflection on the results. Just like the old saying goes "Review what has been learned and you will learn something new" [11]. In the process of reflecting, students will repeatedly strengthen their sense of participation in the experience environment, and through learning new knowledge, they will gain a deeper sense of participation.

College students come from different provinces and their English levels vary greatly. Teachers can help students form small groups with students of different levels, encourage them to experience the situation by themselves and make them become the real subjects of education. When students with different English levels are given equal opportunities to participate in experience teaching, they can experience the situations from dependent to independent, from receptive to creative, from passive learning to active learning. All these can help students to be aware of the real pleasure and enjoyment in the teaching mode so as to achieve the goal of autonomous development and the improvement of the English level of the whole class.

\section{The Application Problems of Experiential Teaching Mode in College English Teaching}

Experiential Teaching Mode can make use of solid teaching resources to enhance students' learning initiative, interest and efficiency, and also develop their English ability, improve their communication skills, and carry out cooperative learning and autonomous learning. Thus students can experience the charm of the language and develop comprehensive application ability so as to achieve better teaching effect. However, just as any teaching mode, Experiential Teaching Mode also has its own disadvantages

\subsection{Teachers' Lack of Ability to Control the Experiential Teaching Class}

The core concept of experiential teaching is experience. In the process of classroom teaching, teachers need to be very familiar with the teaching content and also be able to control the rhythm of classroom teaching and learning. Thus they can not only create corresponding experience situations for students by combining the teaching content and the students' learning basis but also adopt the experiential environment in the appropriate place. However, from the current 
situation of college teaching in China, the application of the experiential teaching does not play its own role. Many college English teachers do not have the ability and relevant knowledge to create corresponding experience environment. Therefore, they usually create situations illogical to reality or a single situation form to attract students' participation in experiential teaching class. In fact, such classes can not reflect the real value of experiential teaching. It is not helpful for the improvement of students' classroom learning quality, the efficiency of classroom teaching and the expansion of students' knowledge level.

\subsection{Teachers' Ignorance of Treating Students as Individuals}

Modern classroom teaching requires more interaction between teachers and students and also more communication among students. Through communication and discussion, teachers can timely understand students' learning situation and students can timely share problems with their teachers and peers. This can help teachers adjust teaching methods to make up for deficiencies and improve students' basic knowledge level. Different students have different learning basis, so it is essential for teachers to create corresponding experience situation and apply corresponding teaching method in accordance with their aptitude. Thus students can communicate with teachers and discuss with peers based on their own level. However, in the current college English classes in China, many teachers ignore the necessity of catering students for all abilities. Students of lower levels will find it difficult to integrate into higher level learning situations even though they can feel the charm of English through experiential learning. If students can not stay with the experience environment for a long time, Experiential Teaching Mode will lose its application values in college English teaching and can not improve students' English learning.

\subsection{Students' Difficulty in Participating in Experiential Teaching}

The essence of applying Experiential Teaching Mode is to provide students with abundant learning experience through creating experience environment. Students can gain more practical experience of English knowledge in the process of communicating with teachers and accumulating knowledge. However, from the real college English classroom teaching situations, many students are in a state of staying away from teaching contents and teaching methods. Some students of higher level can participate in interacting with teachers to gradually strengthen their absorption of English knowledge and improve their learning experience. More students of lower level are unable to realize the value of applying experiential teaching. Some even can not understand experience environment created based on the teaching content or establish good interaction with teachers after participating in the experience environment. The most important premise of applying Experiential Teaching Mode is that students can fully participate in the experience environment. Students can summarize and reflect with the guidance of teachers after entering the experience environment. However, many students 
can not participate in the experience environment because of lack of teachers' guidance and ideological construction and their own language deficiency. Even if they can participate in the experience environment, they are unable to communicate and interact with teachers. This is not benefit for the improvement of students' English learning level.

\section{The Application Suggestions of Experiential Teaching Mode in College English Teaching}

Since there are the above disadvantages, some suggestions are given as follows:

Firstly, college English teachers should overcome difficulties, improve their own ability, be familiar with the teaching content and examine carefully before creating corresponding experience environment. As guiders and supervisors of the classroom, teachers should know clearly what's going on in class, offer immediate help if necessary, timely evaluate students' performance in the experience environment.

Secondly, teachers should make good use of modern technology. In the era of everything linked with Internet, education also faces multi-dimensional opportunities. Teachers should utilize the advantages of technology, especially the Internet, to help provide and think of better ways to choose proper materials and design appropriate experience environment.

Thirdly, students of all levels should try their best to enter and participate in the experience environment. Students of different levels should choose the appropriate role to experience, seek help from teachers when confronting with difficulties.

Fourthly, teachers should pay attention to time allocation. Experiential teaching requires time to experience the environment in class so as to help students gain corresponding situational experience. This would take up time for other teaching content or even lead to failure of accomplishing teaching tasks. So before creating environment, teachers should make a full plan of the whole unit in order to achieve the goal.

\section{Conclusions}

Experiential Teaching Mode has a rich ideological connotation, so the application of Experiential Teaching Mode in college English teaching has important significance. In college English teaching, teachers need to incorporate modern technology and teaching resources to create various experience environments, guide students to enter and participate in experiential teaching and improve the interaction and communication between teachers and students. At the same time, students should cooperate with each other, try their best to participate in experiential teaching, gain corresponding experience to develop their English ability and accumulate experience to finally achieve the qualitative leap.

Although experiential teaching has great potential in college English teaching, there are also some shortcomings of the paper. Firstly, the four basic skills are 
interrelated closely, how to apply Experiential Teaching Mode to improve a specific skill needs to be studied further. Secondly, students are required to enter the experiential environment, but how to judge whether they really participate in it requires further exploration. Thirdly, it takes a lot of time and efforts for the teachers to create good and appropriate environments for the students, whether there are simpler ways to do so still remains unknown.

\section{Conflicts of Interest}

The author declares no conflicts of interest.

\section{References}

[1] Wang, Y.L. (2020) On the Application of Experiential Teaching in Senior High School English Class. Occupation, 14, 95-96.

[2] Wang, Y.C. (1992) Theory of Aesthetic Experience. Baihua Literary and Art Press, Tianjin.

[3] Li, D. (2020) Research on the Application of Experiential Teaching Mode in Japanese Teaching. Frontiers in Educational Research, 3, 87-89.

[4] Kolb, D. (1984) Experiential Learning: Experience as the Source of Learning and Development. Prentice-Hall, New Jersey.

[5] Confucius (2018) The Analects of Confucius. Shanxi People's Education Press, Xi'an.

[6] Wang, J.X. (2011) A Study on the Experiential Teaching in College English Listening in CALL Context.

[7] Wang, N. (2011) Research on the Reasons and Countermeasures of the Lack of Experiential Teaching. Nanjing Normal University.

https://kns.cnki.net/KCMS/detail/detail.aspx?dbname=CMFD2012\&filename $=1011$ 400136.nh

[8] Wang, J. (2021) Effectiveness Study on the Cultivating Mode of College Students' English Autonomous Learning Ability. Journal of Heilongjiang Institute of Technology, 35, 73-76.

[9] You, S.X. and Wang, S.S. (2021) Application of the Experiential Teaching in Tourism English in Secondary Vocational School. Tourism Today, 19, 95-96.

[10] Fan, N.W. (2020) Application of Multimodal Experiential Teaching in College English Teaching Based on Morphology Learning Theory. International Journal of New Developments in Education, 2, 55-57.

[11] Hao, X.X. (2020) The Application of Experiential Teaching Method in English Teaching. International Journal of Intelligent Information and Management Science, 9, 164-167. 